Acta vet. scand. $1973,14,129-146$.

From the Department of Microbiology and Immunology,

Veterinary College of Norway, Oslo.

\title{
THE IN VITRO EFFECTS \\ OF PEPTIDE-PRECIPITATING LIGNOOSULPHONIC ACIDS ON VARIOUS BIOLOGICALLY ACTIVE SUBSTANCES PRODUCED BY OR WITH ACTION ON MICROORGANISMS
}

\author{
By \\ Bjørn Næss and Olav Sandvik
}

\begin{abstract}
NESS, BJØRN and OLAV SANDVIK: The in vitro effects of peptide-precipitating lignosulphonic acids on various biologically active substances produced by or with action on microorganisms. Acta vet. scand. 1973, 14, 129-146. - The effects of lignosulphonic acids on colicins, coliphages, different antibiotics, $\beta$-toxin of Staphylococcus aureus, lecithinases of Clostridium perfringens and of Bacillus cereus, hemolysins of Bacillus cereus and Escherichia coli, the bactericidal effect of lysolecithin and on specific and naturally occurring serum proteinase inhibitors have been studied. It was found that lignosulphonic acids distinctly inhibit the biological activities tested, with the possible exceptions of the inhibitory effects of serum antiproteinases, naturally occurring inhibitors in serum, and the bacteriolytic effect of coliphages. The inhibiting effects are discussed in relation to the use of animal fodder containing lignosulphonic acids, and to the appearance of a selected microbial flora in sulphite spent liquor recipients.
\end{abstract}

lignosulphonic acids; inhibition; enzymes; toxins; antibiotics; colicins; lysolecithin.

It has been shown that lignosulphonic acids inhibit the proteolytic activity of various microbial and animal proteinases (Næss et al. $1973 \mathrm{a}, \mathrm{b}$ ). The lignosulphonic acids probably also inhibit the activity of invertase in the microbial degradation of sucrose to invert sugar (Næss 1972). These observations have stimulated the authors to investigate whether lignosulphonic acids inhibit, or interfere with, other biochemical reactions which may take place in ecosystems of which lignosulphonic acids are a component. This paper deals with the effects of lignosulphonic acids on various biologically active substances produced by or with action on microorganisms. 


\section{MATERIALS AND METHODS}

Lignosulphonic acids. Lignosulphonic acids were prepared by dialysis of a fermented sulphite spent liquor, kindly supplied by Tofte Cellulosefabrik A/S, Hurum, Norway. The liquor used in the present work was tested by the CP-method of Sandvik (1962) and found not to contain detectable amounts of proteolytic enzymes. Dialysis was carried out against running tap water at room temperature for 18 hrs. These lignosulphonic acids are referred to as DSSL (dialyzed sulphite spent liquor). A stock solution ( $\mathrm{pH} 6$ ) was prepared, containing 250 diffusion units of peptide-precipitating lignosulphonic acids per $50 \mu l$ liquor (Næss 1971a). The lignosulphonic acids have been characterized by gel chromatography and determination of the peptide-precipitating ability of the fractions (Hildrum \& Næss 1972). The sodium salt of lignosulphonic acids (LSA), prepared by the procedure of Jantzen (1967), was kindly supplied by Alwatech A/S, Oslo, Norway. These lignosulphonic acids have also been characterized by gel chromatography and determination of the peptide-precipitating ability of the fractions (Næss et al. $1973 \mathrm{~b}$ ). The $\mathrm{pH}$ of the LSA solutions used was adjusted to $\mathrm{pH}$ 6. Various gel chromatography fractions of LSA were prepared as described previously (Næss et al. $1973 \mathrm{~b}$ ). These fractions are hereafter called LSA samples $1,2,3$ and 4 (4\% solutions). LSA sample 1 contains mainly high-molecular weight lignosulphonic acids, LSA samples 2 and 3 lignosulphonic acids of middle molecular weight, and LSA sample 4 low-molecular weight lignosulphonic acids (Hildrum \& Næss).

Strains. The organisms used were: Bacillus cereus (NVH* 322 and NVH 132), Clostridium perfringens (NVH 839), Staphylococcus aureus (NVH 1045), Serratia marcescens (NVH 2672), Escherichia coli phi (kindly supplied by the University Department of Bacteriology, Royal Infirmary Glasgow, Scotland), E. coli strains CL 137, CL 139, K 12 and Citrobacter freundii strain CA 31 , (the four strains producing colicins $\mathrm{E}_{2}, \mathrm{~B}, \mathrm{~S}$ and $\mathrm{A}$ respectively, kindly supplied by Institut Pasteur, Paris, France), E. coli (NVH 2771) isolated from the intestine of a normal pig and E. coli (NVH 2898) hemolytic. T4(r48) andT4(N54) coliphages

* The Culture Collection of the Department of Microbiology and Immunology, Veterinary College of Norway, Oslo, Norway. 
were kindly supplied by Dr. $\emptyset$. Strømnes, University of Oslo, Blindern, Norway. Stock solutions contained $5 \times 10^{8}$ phages per $\mathrm{ml}$.

Media. Nutrient broth and nutrient agar (Dif co $^{\star}$ ) were used as basic media. Blood agar was prepared by the addition to melted and sufficiently cooled nutrient agar of washed or unwashed defibrinated beef blood to a final concentration of $8 \%$ $(\mathrm{v} / \mathrm{v})$.

Egg-yolk agar was prepared by addition of aseptically prepared egg-yolk, to a final concentration of $5 \%(v / v)$, to melted and sufficiently cooled nutrient agar. When using the various systems with, and without, lignosulphonic acids, segments of the agar layers were removed, and replaced by pouring in agar containing the desired concentration of lignosulphonic acids (DSSL or LSA). These agar plates are referred to as DSSL- or LSA-nutrient, -blood or -egg-yolk agar plates.

Incubation. All incubations were performed at $37^{\circ} \mathrm{C}$ except for Serratia marcescens which was incubated at $30^{\circ} \mathrm{C}$.

Demonstration of colicin effect. DSSL- and LSA-nutrient agar plates were used with $10 \%$ (v/v) DSSL or $2.5 \%$ (w/v) LSA, respectively, unless stated otherwise. A loopful of cultures of each of the various colicin producing organisms was streaked on the agar surface (Abbott $\&$ Shannon 1958), the streaks being made perpendicular to the border between the agar layers from the lignosulphonic acid-containing area to the lignosulphonic acid-free area. After 48 hrs. aerobic incubation, the E. coli confluent colonies were removed and the agar plates treated with chloroform for $2 \mathrm{hrs}$., the chloroform being placed in the cover of the inverted petri dish. Parallel, anaerobically incubated plates were treated in the same way. Circular sterile filter papers of the same diameter as the petri dishes saturated with $3 \mathrm{hrs}$. nutrient broth cultures of colicin-sensitive strains of E. coli, were placed on the agar surfaces for 5 min., and after removal of the filter papers the plates were incubated overnight aerobically, and anaerobically.

To study the effects of various gel chromatography fractions of LSA on the bacteriostatic effect of colicins, $50 \mu l$ of the LSA fractions $(4 \%)$ were transferred to a rectangular well about 3

- Difco Laboratories Inc., Detroit, Michigan, USA. 
by $10 \mathrm{~mm}$ in the nutrient agar and incubated overnight, after which the strain of $E$. coli to be tested was streaked on the agar surface and the procedure described above followed.

Demonstration of the bacteriolytic effect of coliphages. Three $\mathrm{ml}$ of $3 \mathrm{hrs}$. nutrient broth cultures of coliphage-sensitive strains of E. coli were poured on to the surfaces of DSSL- $(10 \% \mathrm{v} / \mathrm{v})$ nutrient agar plates and, after removing the excess broth, the surfaces were allowed to dry at room temperature for $30 \mathrm{~min}$., and drops of the coliphage suspensions placed on the seeded plates, and incubated overnight. The agar layer method (Clowes \& Hayes 1968) was also used, pouring over the surface of a DSSL-nutrient agar plate, $2.5 \mathrm{ml}$ of molten "soft" agar (Difco Bacto agar) added $0.2 \mathrm{ml}$ of an overnight broth culture of the coliphage-sensitive strain of $E$. coli and $0.1 \mathrm{ml}$ of a diluted phage suspension, and incubated overnight. By this method a single phage particle will produce a plaque. Soft agar with and without $10 \%$ DSSL was also used in the agar layer method, the soft agar containing bacteria and suitable dilution of bacteriophages being poured over nutrient agar plates. The bacteriophage dilution used, resulted in about 100 plaques per plate. The addition of phages to the soft agar was performed about $30 \mathrm{~min}$. after the addition of the bacteria.

Demonstration of the effects of different hemolysins, lecithinases and of $\beta$-toxin of Staphylococcus aureus. For these investigations, the strains were streaked on LSA $(2.5 \% \mathrm{w} / \mathrm{v})$-egg-yolk and -blood agar plates as described above, and the plates incubated overnight. The LSA-egg-yolk agar plate seeded with Cl. perfringens was incubated anaerobically, the others aerobically. The lecithinase and $\beta$-hemotoxic effects were also demonstrated by transferring samples of the supernatants of overnight broth cultures of $B$. cereus and $S$. aureus to wells ( $7 \mathrm{~mm}$ diameter) in LSA-egg-yolk agar and LSA-blood agar plates respectively. The plates were incubated overnight. These plates contained $0.01 \%$ of thimerosal as microbicidal agent.

Demonstration of the neutralization of the bactericidal effect of lysolecithin. Lysolecithin (alpha-gamma (1, 3) lysolecithin, synthetic, no. 8874 from $\mathrm{NBC}^{\star}$ ) agar plates were prepared by adding $0.1 \mathrm{ml}$ of a solution containing $5 \mathrm{mg}$ lysolecithin per $\mathrm{ml}$,

- Nutritional Biochemicals Corporation, Cleveland, Ohio, USA. 
to each $10 \mathrm{ml}$ of nutrient agar (Sandvik \& Hфyem 1971). Three $\mathrm{ml}$ of a $3 \mathrm{hrs}$. broth culture of a lysolecithin-sensitive strain of S. aureus was poured over the agar surface and, after removing the surplus and drying the agar for $30 \mathrm{~min}$. at room temperature, the solutions to be tested were transferred to wells in the agar ( $7 \mathrm{~mm}$ diameter) in aliquots of $0.025 \mathrm{ml}$. In addition to LSA and fractions of LSA, horse serum was also tested.

Demonstration of the growth inhibiting effect of some antibiotics. LSA (2.5\%) -nutrient and -blood agar plates were used, $3 \mathrm{ml}$ of a $3 \mathrm{hrs}$. broth culture of the test organisms was poured onto the agar surface. After removing the surplus and drying for 30 min. at room temperature, antibiotic discs (Neo-sensitabs from A/S Rosco, Taastrup, Denmark) (Table 1) were placed on the seeded agar surface, and the plates incubated overnight. The growth-inhibiting effect of gentamycin (Schering*) was also tested in broth cultures (Zähner \& Maas 1972), in the absence and presence of $2.5 \% \mathrm{LSA}$, using $0.1 \mathrm{ml}$ of a $3 \mathrm{hrs}$. broth culture of $\mathrm{S}$. aureus as inoculum. The growth was estimated by measuring the absorbance at $610 \mathrm{~nm}$ in a photometer (Spectronic ${ }^{\star *} 20$ ) using unseeded broth as blank.

Demonstration of the proteinase inhibiting effect of specific and naturally occurring serum inhibitors. A specific antiproteinase was produced against Subtilopeptidase A from a special strain of Bacillus subtilis (Type VIII, Lat 17B-2770 from Sigma ${ }^{\star \star *}$ ) in rabbit as described by Sandvik (1969). The so-called electrophoretic Casein Precipitation test (electrophoretic CPI-test) (Fossum 1970) was used for the separation of the antiproteinases and the naturally occurring proteinase inhibitors in the immune serum. By this procedure, the naturally occurring inhibitors are localized in the $\alpha$ - and $\beta$-globulins, on the anode side of the line of application, while induced antibodies occur in the region of the $\gamma$-globulins. After transferring the serum electrophorogram from the paper electrophoresis strip (LKB equipment for paper electrophoresis $^{\star \star \star *}$ ) to an ordinary caseinate agar plate (Sandvik 1962), and to a caseinate agar plate containing $10 \%$ (v/v) DSSL, followed by "developing” the plates with filter paper strips

* Schering Corp., Bloomfield, New Yersey, USA.

* Bausch \& Lomb Inc., Rochester, USA.

* * Sigma Chemical Company, St. Louis, Missouri, USA.

*** LKB, Stockholm, Sweden. 
moistened with the enzyme solution, zones of inhibition of the enzyme-produced precipitation occur where inhibitors, or antiproteinases, are found.

\section{RESULTS}

The bactericidal effects of colicins could be inhibited by lignosulphonic acids, but the extent of inhibition varied from weak to total inhibition when $10 \%$ (v/v) DSSL was incorporated in the agar (Fig. 1a). The inhibition of the colicin produced by

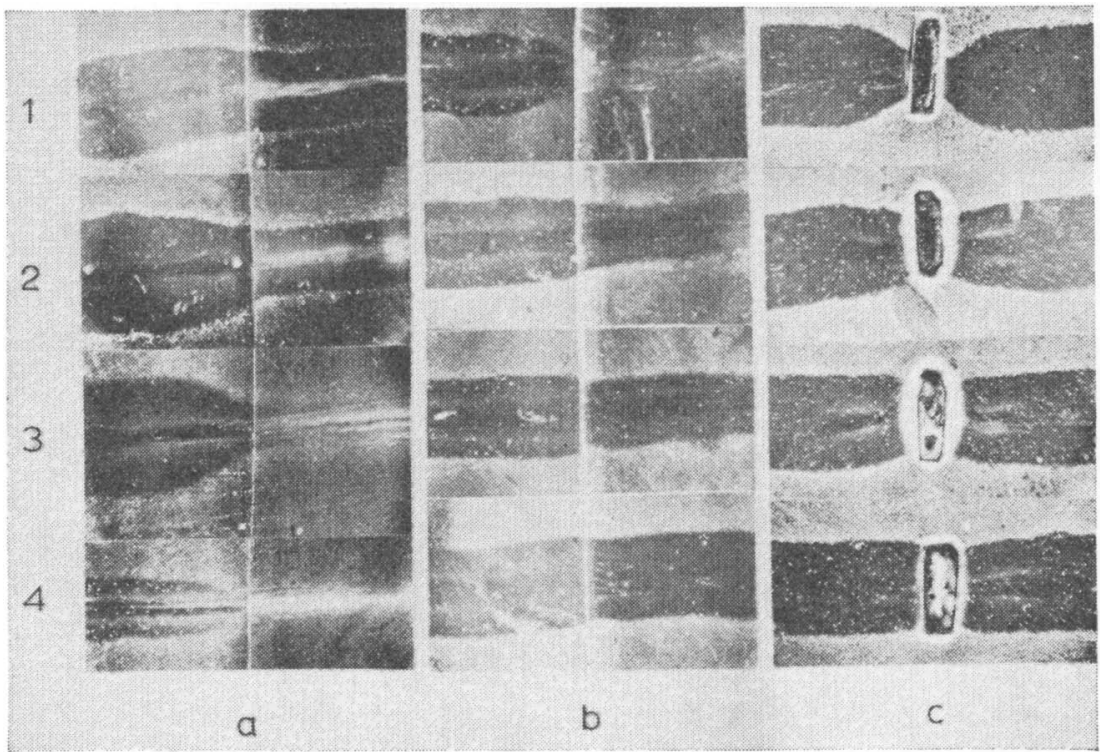

F igure 1 a. The effect of colicins on the growth of Escherichia coli phi (1,2 and 3), and on Escherichia coli (NVH 2771) (4), in the absence of (left side), and the presence of (right side) lignosulphonic acids in dialysed sulphite spent liquor (DSSI). The colicin-producing strains are (downwards) : Escherichia coli strain CL 139, CL 137, Citrobacter freundii CA 31 and Escherichia coli CL 137.

b. The effect of colicin, produced by Escherichia coli CL 137 on the growth of Escherichia coli (NVH 2771), in the absence of (left side), and the presence of (right side) various concentrations of lignosulphonic acids (DSSL). The concentrations of DSSL are (downwards) : $5 \%(\mathrm{v} / \mathrm{v}), 2.5 \%, 1.2 \%$ and $0.6 \%$.

c. The effect of colicin, produced by Escherichia coli CL 137 on the growth of Escherichia coli (NVH 2771) in the presence of various gel chromatography fractions of the sodium salt of lignosulphonic acids (LSA in $4 \%$ solutions). The fractions used are (downwards): LSA samples $1,2,3$ and 4 . 


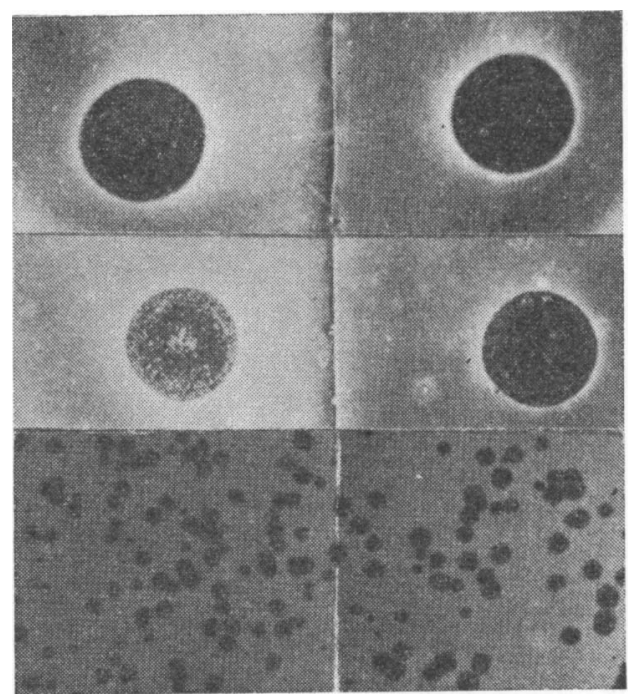

F ig u r e 2. The effect of coliphages on the growth of Escherichia coli CL 137 (the upper row) and of Escherichia coli K12 (the lower two rows) in the absence of (left side), and the presence of (right side) lignosulphonic acids (DSSL). The coliphages used are (downwards) : T4 (N54), T4 ( $\mathrm{r} 48$ ) (placed as drops on seeded agar plates) and T4 (r48) (poured in mixture with the bacteria and molten soft agar over the surface of the agar plate). An undiluted suspension of T4 (N54) phages and diluted suspensions of T4 (r48) phages are used.

E. coli, strain CL 137, was total when $5 \%$ of DSSL was used in the agar. This colicin was slightly inhibited when $1.2 \%$ DSSL was used, but no inhibition was observed with $0.6 \%$ (Fig. 1b). When various concentrations of LSA were used, total inhibition was seen at $2.5 \%(\mathrm{w} / \mathrm{v})$ and a slight inhibition of the colicin effect observed at $0.6 \%$, but no inhibition occurred with $0.3 \%$ LSA. The inhibition areas on the plates incubated anaerobically were approximately as large as those incubated aerobically. From Fig. 1c, it can be seen that the high-molecular weight lignosulphonic acids (LSA sample 1) lead to the greatest inhibition on the bactericidal effects of colicin. The inhibitory effect decreases as the molecular weight decreases. Little inhibition can be seen when using the low-molecular weight lignosulphonic acids (LSA sample 4) in the agar well. The bactericidal effect of two random coliphages did not seem to be inhibited by the concentrations of DSSL used (Fig. 2). Using the agar layer method with and without $10 \%$ DSSL in the soft agar poured over nutrient agar plates, led to similar results as shown in the right and left side 


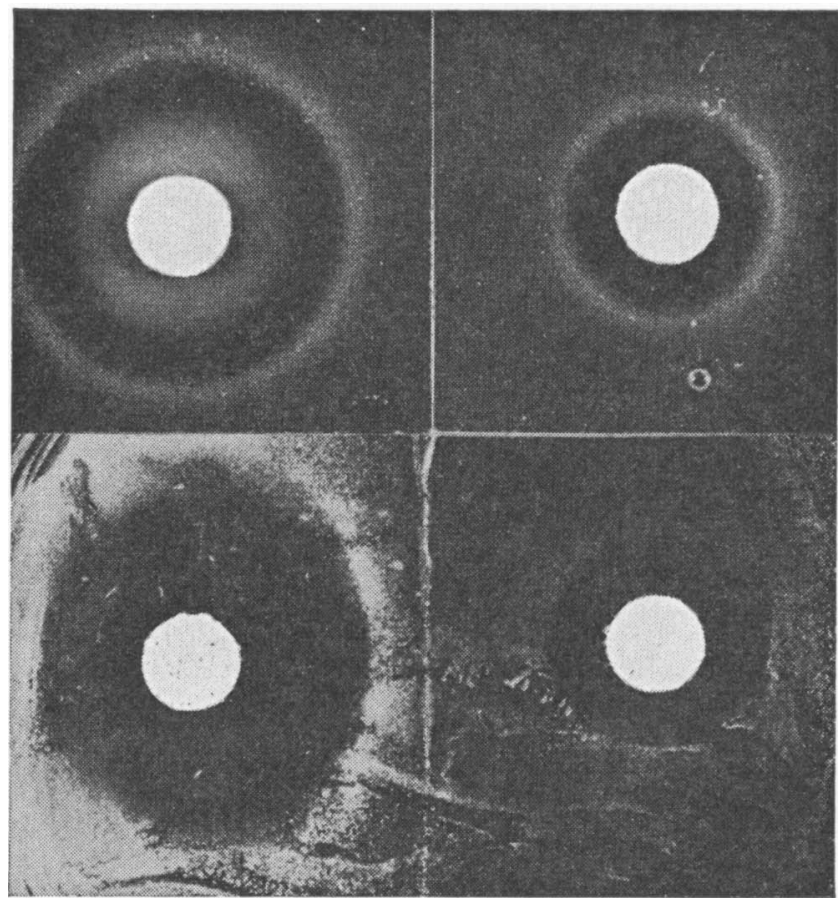

F i g u r e 3. The bacteriostatic effect of two antibiotics on the growth of Staphylococcus aureus on blood agar (upper) and of Serratia marcescens on nutrient agar (lower) in the absence of (left side), and the presence of (right side) lignosulphonic acids (LSA) in the agar. The antibiotics used were (downwards) gentamycin and neomycin.

T a ble 1. Growth inhibition of Staphylococcus aureus and Serratia marcescens caused by different antibiotics, in the absence and presence of lignosulphonic acids (LSA) in the agar plates.

\begin{tabular}{lccccc}
\hline & \multicolumn{3}{c}{ Growth inhibition } & (mm zone diameter) of \\
\cline { 2 - 3 } Antibiotic disc & \multicolumn{2}{c}{ Staphylococcus aureus } & & Serratia marcescens \\
\cline { 2 - 3 } \cline { 5 - 6 } & without LSA & with 2.5 \% LSA & & without LSA & with 2.5 \% LSA \\
\hline Bacitracin & 20 & 16 & & $9^{*}$ & 9 \\
Gentamycin & 28 & 17 & & 27 & 16 \\
Kanamycin & 30 & 23 & & 29 & 23 \\
Neomycin & 27 & 18 & & 25 & 17 \\
Penicillin & 30 & 30 & & 9 & 9 \\
Polymyxin & 17 & 9 & & 20 & 9 \\
Streptomycin & 27 & 24 & & 26 & 24 \\
Tetracyclin & 24 & 22 & & 9 & 9 \\
\hline
\end{tabular}

- $9 \mathrm{~mm}$ means no visual growth-inhibiting effect of the antibiotic. 


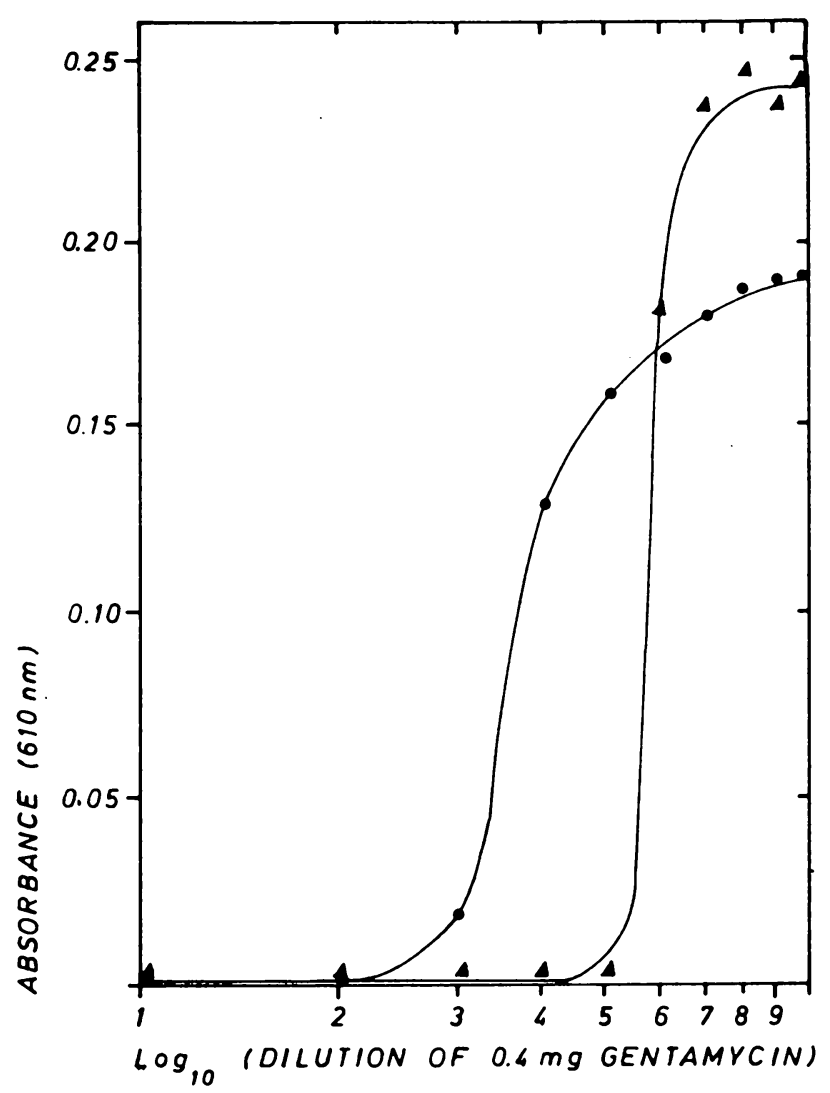

F i g u re 4. The effect of adding gentamycin to broth cultures of Staphylococcus aureus with (O-O) and without $(-<)$ lignosulphonic acids (LSA). The last plot on each curve is the absorbance of the broths without antibiotic.

of the lower part of Fig. 2. No significant difference $(P>0.05)$ in the number of plaques could be found when comparing 15 plates with and 15 corresponding plates without DSSL. From Fig. 3 and Table 1 it can be seen that the bacteriostatic or bactericidal effect of various antibiotics is inhibited by LSA, but the extent of inhibition varies with the different antibiotics tested. When testing the effect of gentamycin on the growth, in broth cultures of $\mathrm{S}$. aureus, in the absence and presence of $2.5 \%$ LSA, the highest concentrations of antibiotic resulting in demonstrable growth, were $0.4 \times 10^{-6} \mathrm{mg}$ and $0.4 \times 10^{-3} \mathrm{mg}$, respectively (Fig. 4). It can be seen that LSA itself has a slight depressive effect on the growth of $S$. aureus. 


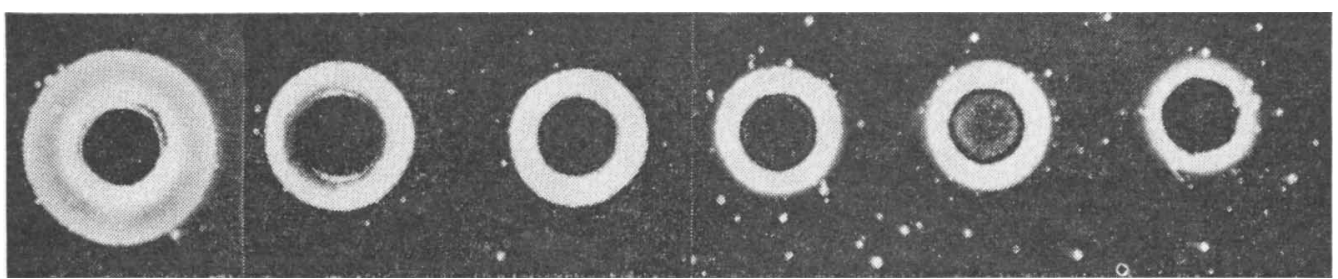

F igure 5. Growth of a lysolecithin-sensitive strain of Staphylococcus aureus around agar wells containing (from left to right): Horse serum, $5 \%$ I.SA solution, LSA samples $1,2,3$ and 4 (4\% solutions).

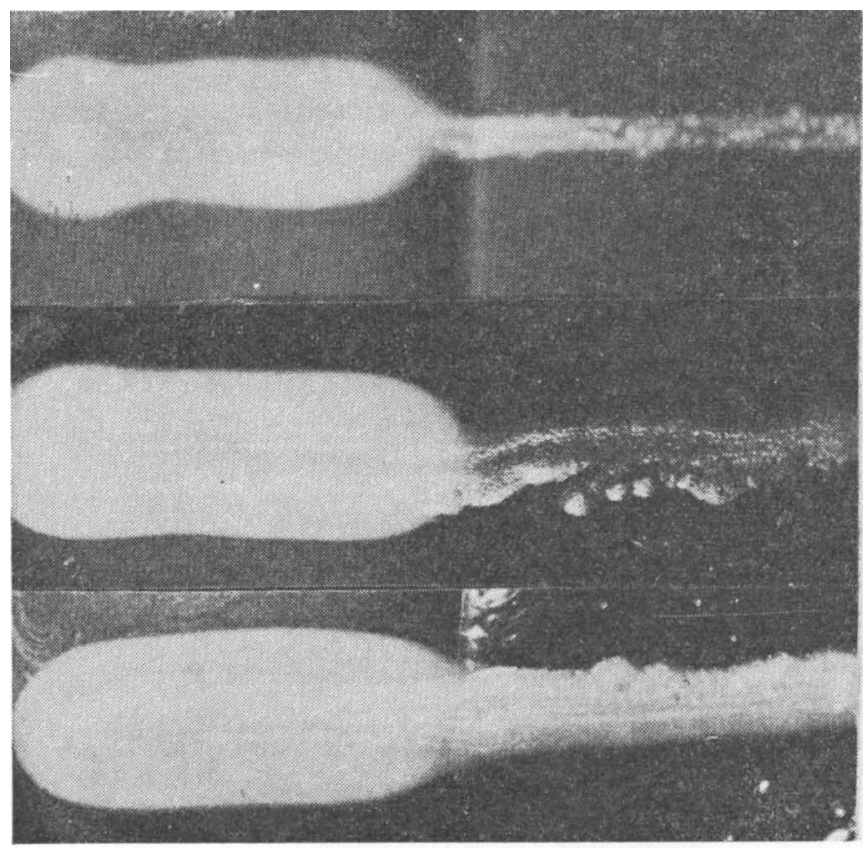

a

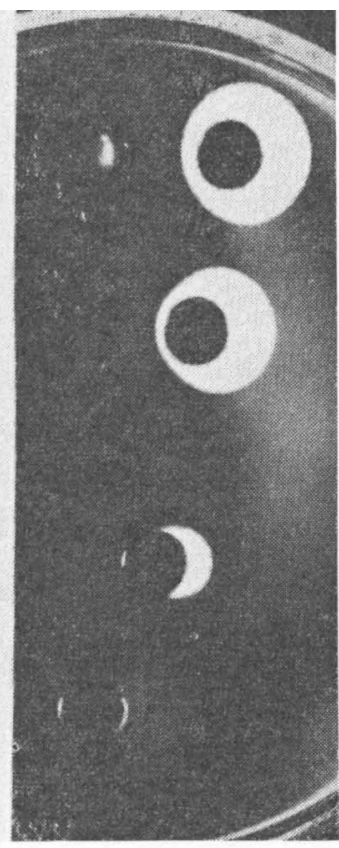

b

F igu r e 6 a. Precipitation zones caused by lecithinase in egg-yolk agar without (left side), and with (right side) lignosulphonic acids (ISA). Strains used (downwards): Clostridium perfringens, Bacillus cereus (NVH 132), Bacillus cereus (NVH 322).

b. Precipitation zones caused by the supernatant of a broth culture of Bacillus cereus (NVH 132) applied into wells in an egg-yolk agar prepared with (left side), and without (right side) lignosulphonic acids (LSA). 


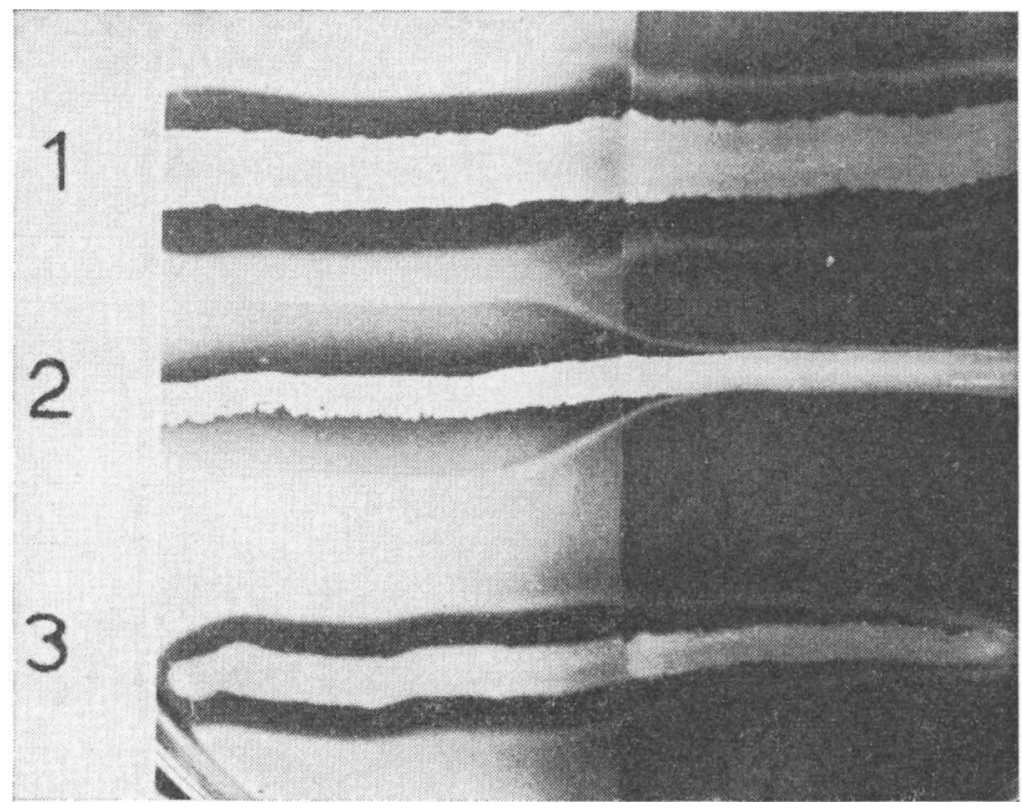

Figure 7. Hemolytic zones caused by Bacillus cereus (NVH 322) (1) and Escherichia coli (NVH 2898) (3), and $\beta$-toxic zone caused by Staphylococcus aureus (2), on washed bovine erythrocytes in agar prepared without (left side), and with (right side) lignosulphonic acids (LSA).

In the experiments with gentamycin it was observed that this antibiotic, in solution, forms a yellow-brown precipitate with LSA.

Lignosulphonic acids neutralize the bactericidal effect of lysolecithin (Fig. 5). The neutralization of the lysolecithin effect is indicated by the occurrence, around the well, of a distinct zone of growth in the otherwise growth-inhibited area. Some isolated lysolecithin-resistent mutants are also found elsewhere on the plates. The lysolecithin-neutralizing effect was observed for all the LSA samples tested, but the degree of neutralization decreased with decreasing molecular weight of the lignosulphonic acids.

The effect of LSA upon lecithinase produced by $\mathrm{Cl}$. perfringens and by B. cereus is shown in Fig. 6a. When $2.5 \%$ LSA was incorporated in the egg-yolk agar, no yellow-white precipitation, caused by lecithinase, was seen around the growth zone of $\mathrm{Cl}$. perfringens, and of one strain of B. cereus tested. For the other 


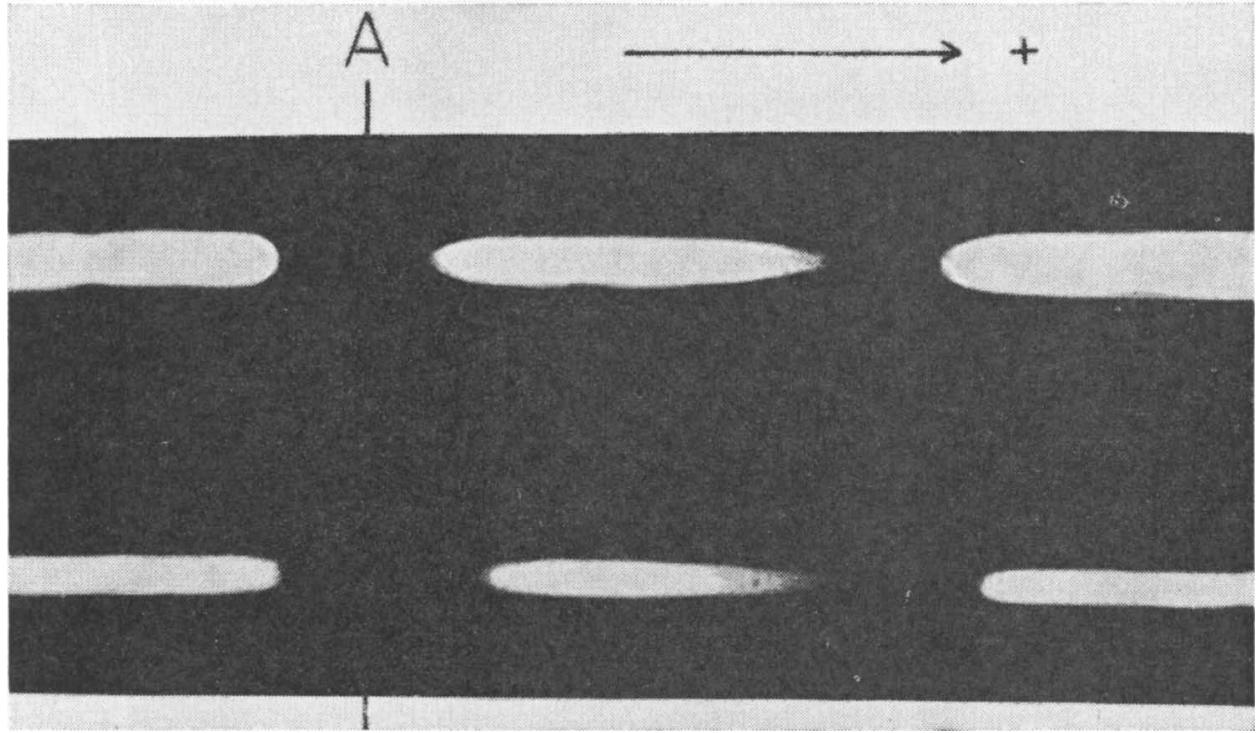

F i g u r e 8. Electrophoretic CPI-test of serum from rabbit, immunized with Bacillus subtilis proteinase. The electrophoresis was carried out in $0.05 \mathrm{M}$ phosphate buffer at $\mathrm{pH} 6.2$ for $18 \mathrm{hrs}$. The zone of inhibition near the line of application (A) is due to the induced antienzyme against Bacillus subtilis proteinase, while the zone of inhibition on the anode side is due to the naturally occurring inhibitors in the serum. Upper part of the figure: No DSSL present in the agar. Lower part of the figure: $10 \%(\mathrm{v} / \mathrm{v})$ DSSL present in the agar. The concentration of proteinase solution used for the development was 0.001 $\mathrm{mg} / \mathrm{ml}$.

strain of B. cereus, the lecithinase activity was reduced, but not totally inhibited, under the same conditions. When using the latter strain of $B$. cereus, inhibition could be demonstrated when 0.6\% LSA was incorporated in the egg-yolk agar, but not when $0.3 \%$ was used. In Fig. $6 \mathrm{~b}$, supernatant samples from an overnight broth culture of $B$. cereus were applied in wells in an LSAegg-yolk agar plate. As the precipitation caused by the lecithinase was reduced by increasing concentrations of LSA, placing the wells nearer the source of this latter component, there is a direct inhibiting effect of LSA on the enzyme activity.

The effect of the $\beta$-toxin produced by $S$. aureus on erythrocytes in nutrient agar was almost totally inhibited in the presence of $2.5 \%$ LSA (Fig. 7). When applying the supernatant of an overnight culture of $\mathrm{S}$. aureus into wells in an LSA-blood agar 
plate, the $\beta$-toxic effect of the supernatant was reduced, when the concentration of LSA was increased, similarly to the corresponding experiment with the lecithinase of $B$. cereus. The hemolytic effect of one strain each of B. cereus and E. coli was only inhibited to a slight extent when $2.5 \%$ LSA was incorporated in the blood agar. Fig. 8 shows the effect of rabbit serum antiproteinases, and naturally occurring proteinase inhibitors, against B. subtilis proteinase in the presence and absence of DSSL. The somewhat less distinct precipitation caused by the enzyme in the presence of lignosulphonic acids, is due to the inhibitory effect of lignosulphonic acids on proteinases (Næss et al. 1973 a). It can be seen that the activity of specific serum antiproteinases, and naturally occurring proteinase inhibitors, can still be distinctly demonstrated in the presence of $10 \%$ ( $v / v)$ DSSL.

\section{DISCUSSION}

The present experiments, together with previous observations (Næss et al. $1973 \mathrm{a}, \mathrm{b}$ ), show that lignosulphonic acids have inhibitory effects on a number of biological systems. These effects should be thoroughly considered when lignosulphonic acids are incorporated in various environments. According to Rettger (1928), the large intestine of man and lower mammals may be considered as a veritable culture tube in which definite bacterial types appear to be constantly struggling to gain supremacy. To that end, they use all the known and unknown mechanisms of antibiosis. Antagonistic manifestations, due to E. coli or other enteric bacteria are well known (e.g. Fredericq 1948). In this connection the inhibiting ability of lignosulphonic acids upon the antibiotic effect of various colicins, demonstrated in the present work, is of particular interest. Thus, there is a possibility that lignosulphonic acids present in animal feed-stuffs (e.g. used as pelletizing agent) can disturb the balanced microbial ecosystem in the intestine. This disturbance may not be expressed in direct clinical manifestations, but may be a general stress factor. It should be remembered that the strains studied in this work, produced active colicins both anaerobically and aerobically, as measured by the width of the growth inhibition area on the agar surface. They may thus be considered active factors in the digestive tract under normal conditions. 
No visible inhibition of the antibiotic effect of coliphages was observed with lignosulphonic acids in the present work. Although bacteriophages can reproduce themselves, and are thus distinct from colicins, there are close similarities between the behavior of colicins and bacteriophages. Both require the presence of specific cell receptors for their lytic action and these may be the same for a colicin and a bacteriophage (Nomura 1967). The difference in the sensitivity of colicins and coliphages to lignosulphonic acids indicates that the inhibition of colicins is on the production of colicin or on colicin itself, rather than on the receptors.

The effect of lignosulphonic acids on various antibiotics is rather interesting as both may theoretically be incorporated at the same time in animal fodder. Thus the microbicidal effect of the antibiotic may be more, or less, reduced in the presence of lignosulphonic acids. It is also interesting to note that lignosulphonic acids may inhibit the effect on the animal organism of various bacterial products (such as hemotoxins, lecithinases and proteinases). On the other hand, the effects of naturally occurring bactericidal substances may also be inhibited. When lignosulphonic acid-sensitive antibiotics are included in the lignosulphonic acid-containing feed, the system is still more complicated.

In natural ecosystems such as the animal body, and various extra-animal environments, microorganisms often exist in the presence of more, or less, complex lipids. Lysolecithin is a possible product from the lecithin catabolism of microorganisms. It has been shown (Sandvik \& Høyem 1969, 1971) that lysolecithin has a growth-inhibiting effect on a number of different bacteria and that various factors are able to neutralize the bactericidal effect of lysolecithin. Similarly, it was demonstrated in this work that the lignosulphonic acids are able to neutralize the bactericidal effect of lysolecithin (Fig. 5). The significance of this neutralizing effect of lignosulphonic acids in a possible microbial decomposition of lecithin via lysolecithin is, however, uncertain.

The inhibiting effect of lignosulphonic acids on the activity of various extracellular microbial enzymes and toxins, as demonstrated in this and previous works (Næss et al. 1973 a and b), may indicate that a number of biological systems in the intestine are inhibited, or interfered with to some extent, and may be 
general stress factors, as suggested above. Although the inhibiting effect of lignosulphonic acids on bacterial toxins may be beneficial for the host, the overall effect on the host is most likely highly negative.

Colicins seem to be among the most sensitive of the biological systems investigated, to lignosulphonic acids, as a slight inhibiting effect was observed when the concentrations in the agar of DSSL and LSA were as low as $1.2 \%(\mathrm{v} / \mathrm{v})$ and $0.6 \%(\mathrm{w} / \mathrm{v})$, respectively. These levels of lignosulphonic acids should be remembered when considering the amounts of DSSL and LSA which could be permitted used in animal fodder, but feeding experiments are necessary to elucidate the upper acceptable level of lignosulphonic acids in animal feed.

As shown for the B. cereus produced lecithinase, it seems clear that LSA has an inhibitory effect on the enzyme activity, but whether LSA, in addition, inhibit the production of lecithinase, was not elucidated.

The mechanisms of the inhibitory reactions found in this work, are probably complex. The general affinity of the lignosulphonic acids to form complexes or precipitates with substances of protein nature (Næss $1971 \mathrm{~b}$ ) may, however, be responsible for some of the inhibitory reactions on colicins, enzymes and toxins. More uncertain is the mechanism of inhibition of the effects of antibiotics and lysolecithin. As for gentamycin, it was found that this antibiotic was precipitated with LSA, and this may be of importance for the inhibitory effect. Gentamycin is an aminoglycoside antibiotic (Jacoby \& Gorni 1967), the aminogroups of which may be of importance for the precipitation with LSA (Næss 1971b). On the other hand, only traces of an inhibitory effect were found for streptomycin, which is also an aminoglycoside antibiotic.

It is surprising that only little or no visible effect of lignosulphonic acids was seen on protein components such as antiproteinases and naturally occurring serum inhibitors against the B. subtilis proteinase (Fig. 8) although this is in accordance with previous observations on serum inhibitors against Aspergillus oryzae proteinases, bovine trypsin and Pseudomonas aeruginosa proteinase in peptide-lignosulphonic acid-precipitate agar (Næss 1971c, d). However, the balanced relation between the effects of various proteinases and proteinase inhibitors in the animal seems even more complicated in the presence of lignosulphonic acids. 
The biological effects of lignosulphonic acids studied in the present work, together with the effects previously described (Næss et al. $1973 \mathrm{a}, \mathrm{b}$ ) can explain some of the depressed weight gain of the pigs receiving $13 \%$ LSA in the diet (Næss \& Fjølstad 1973). These pigs had diarrhea almost constantly during the experimental period of 12 weeks. The diarrhea should be considered in relation to possible disturbances in the balanced microbial ecosystem of the digestive tract, and the dysfunction of the digestive enzymes of the host. Diarrhea, depressed weight gain, stagnation and even fatality would not be too unexpected results of these types of conditions.

It has been demonstrated that lignosulphonic acids inhibit the growth rate of a commercial strain of Candida utilis and its degradation of various sugars (Næss 1972). These results, in addition to the inhibitory effect on various biological systems demonstrated in the present work, may indicate that rivers, fiord basins and lakes into which sulphite spent liquors are released, favour the selection of certain microorganisms. In this connection it may be mentioned that species belonging to the genera Sphaerotilus, Fusarium and Leptomitis often dominate the microbial flora in sulphite spent liquor recipients (Schmidt 1967, Nissen 1966). From an ecological point of view it would be of importance to carry out investigations to elucidate the extent to which the lignosulphonic acids inhibit or interfere with biochemical reactions of species from the said genera.

\section{REFERENCES}

Abbott, J. D. \& R. Shannon: A method for typing Shigella sonnei, using colicin production as a marker. J. clin. Path. 1958, 11, $71-77$.

Clowes, R. C. \& W. Hayes: Experiments in microbial genetics. Blackwell Scientific Publications, Oxford, England 1968, 6-7.

Fossum, $K$.: Proteolytic enzymes and biological inhibitors II. Naturally occurring inhibitors in sera from different species and their effect upon proteolytic enzymes of various origin. Acta path. microbiol. scand. Section B, 1970, 78, 605-618.

Fredericq, P.: Actions antibiotiques réciproques chez les Enterobacteriaceae. (Antibiotic interactions with Enterobacteriaceae). Rev, belge Path. 1948, 19, Suppl. 4, 1-9.

Hildrum, K. I. \& B. Næss: Gel filtration of lignosulphonic acids and peptide-precipitating abilities of the separated fractions. Acta vet. scand. $1972,13,293-304$. 
Jacoby, G. A. \& L. Gorni: The effect of streptomycin and other aminoglycoside antibiotics on protein synthesis. In Antibiotics. D. Gottlieb \& P. D. Show (ed.). Vol. I. Springer Verlag, New York 1967, 726-747.

Juntzen, L.: Lignoprotein, animal food. Aktieselskapet Christiania Portland Cementfabrik. Brit. 1.092.628 (Cl.C07g), Nov. 29, 1967. Appl. Nov. 26, 1964.

Nissen, T. V.: Mikroorganismenes liv. (The life of microorganisms). Teknisk Forlag, København 1966, 138.

Nomura, M.: Colicins. In Antibiotics. D. Gottlieb \& P. D. Show (ed.). Vol. I. Springer Verlag, New York 1967, 696-704.

Næss, B.: Peptide-lignosulphonic acid precipitation zones in agar gel. A direct microquantitative procedure for the determination of peptide-precipitating lignosulphonic acids in aqueous solution. Acta vet. scand. 1971 a, $12,583-591$.

Næss, $B$.: The precipitation of peptides and proteins by lignosulphonic acids. Acta vet. scand. $1971 \mathrm{~b}, 12,572-582$.

Næss, B.: The effect of proteinase-digested peptide-lignosulphonic acid complexes, dipeptides and amino acids on the formation of peptide-lignosulphonic acid precipitates. Acta agric. scand. $1971 \mathrm{c}, 21,199-206$.

Næss, B.: The effect of microbial and animal proteinases on peptideand protein-lignosulphonic acid complexes in agar gel. Acta vet. scand. $1971 \mathrm{~d}, 12,592-600$.

Næss, B.: The interactions of peptide-precipitating lignosulphonic acids and the fermentation of various sugars by a strain of Candida utilis. Acta vet. scand. 1972, 13, 505-519.

Næss, B. \& M. Fjølstad: The effects of feeding peptide-precipitating lignosulphonic acids in various concentrations to growing pigs. Acta vet. scand. 1973, 14, 147-159.

Næss, B., K. Fossum \& O. Sandvik: The effects of peptide-precipitating lignosulphonic acids on the in vitro proteolytic activity of some animal and microbial proteinases. Acta vet. scand. 1973a, 14, 107-117.

Næss, B., O. Westbye, K. I. Hildrum \& I. Nafstad: The effects of peptide-precipitating lignosulphonic acids on the proteolytic activity of pepsin in vitro and on the response of pigs to an ulcer inducing diet. Acta vet. scand. $1973 \mathrm{~b}, 14,44-56$.

Rettger, L. F.: Bacteria of the intestinal tract. In The Newer Knowledge of Bacteriology and Immunology. E. O. Jordan \& I. S. Falk (ed.). Univ. Chicago Press 1928, 639.

Sandvik, 0. : Studies on casein precipitating enzymes of aerobic and facultatively anaerobic bacteria. Thesis. Veterinary College of Norway, Oslo 1962.

Sandvik, O.: Enzymo-serological comparison of proteolytic enzymes produced by Salmonella species and other enterobacteria. Acta vet. scand. $1969,10,225-233$. 
Sandvik, O. \& T. Høyem: Inhibitory effect of lysolecithin on bacterial growth. Acta path. microbiol. scand. 1969, 77, 283-290.

Sandvik, $0 . \&$ T. Høyem: Factors neutralizing the bacteriocidal effect of lysolecithin. Acta vet. scand. 1971, 12, 402-416.

Schmidt, H.: Sulfitablauge und Wasserwirtschaft. (Sulphite spent liquor and water science). In Verwertungsgebiete für Sulfitablauge. (Applications of sulphite spent liquor). F. Melms \& K. Schwenzon (ed.). VEB Deutscher Verlag für Grundstoffindustrie, Leipzig 1967, 465-491.

Zähner, H. \& W. K. Maas: Biology of Antibiotics. Springer Verlag, New York 1972, 26.

\section{SAMMENDRAG}

In vitro virkninger av peptidpresipiterende ligninsulfonsyrer på forskjellige biologisk aktive stoffer, produsert av eller med virkning pă mikroorganismer.

En har studert virkninger av ligninsulfonsyrer på coliciner, colifager, forskjellige antibiotika, $\beta$-toksin fra Staphylococcus aureus, lecitinaser fra Clostridium perfringens og Bacillus cereus, hemolysiner fra Bacillus cereus og Escherichia coli, på den baktericide effekt av lysolecithin, og på spesifikke og naturlige forekommende antiproteinaser i serum. Det ble vist, at ligninsulfonsyrer har hemmende virkning på de unders $\varnothing$ kte biologiske aktiviteter, muligens unntatt effekten av antiproteinaser, naturlig forekommende inhibitorer $i$ serum og på den bakteriolytiske effekt av colifager.

Den hemmende virkning har en diskutert i relasjon til bruken av fórstoffer som inneholder ligninsulfonsyrer og i forhold til den selekterte mikrobielle flora en finner i resipienter for sulfittlut.

(Received May 29, 1972).

Reprints may be requested from: Bjørn Næss, Department of Microbiology and Immunology, Veterinary College of Norway, Postbox 8146, Oslo Dep., Oslo 1, Norway. 